legislation of Ukraine, since it does not cohere with the concept, purpose, and implementation mechanism of such rights. This right is not dependent on the subject's other civil rights; it is provided for by law according to territorial criteria; it has no functional prescription and purpose like other pre-emption rights. In addition, the right to pre-emptive purchase of agricultural land implies corruption risks and creates preconditions for rights abuse. Based on the conclusions, the author proposes to improve the legislation on the purchase and sale of agricultural land by repealing part 2 of articul 130 of the Land Code of Ukraine. Gaps in regulating and imperfection of the formulating of the norm of part 2 of articul 130 of the Civil Code of Ukraine do not provide appropriate conditions for the effective implementation and effective protection of this right. As a result, the solution of existing problems in the field of law enforcement of this norm can be carried out only on the basis of such principles of civil law as reasonableness, good faith, freedom of contract and judicial protection of civil law and interest.

Key words: pre-emption right, purchase-sale, agricultural land, principles of civil law.

УДК 347.124

DOI https://doi.org/10.32782/2409-4544/2020-1/11

Погребняк В.

\title{
Окремі проблеми волевиявлення у ході виникнення договірних суб'сктивних цивільних прав
}

Стаття присвячена дослідженню ролі волевиявлення в ході виникнення суб'єктивних цивільних прав при формуванні договірного цивільних правовідносин. Відповідна юридична схематизація розглядається, зокрема, з позицій принципу свободи волі і вільного волевиявлення, а також в контексті правозастосовчої практики вищих судових інстанцій України. Автор розглядає проблему укладення договору на підставі рішенням суду, а також аналізує сучасні тенденції практики правореалізації в частині оформлення договорів. Формується висновок про те, що механізм укладення договорів на підставі рішенням суду, який знайшов відображення на рівні положень Господарського кодексу України, може бути впроваджений і на рівні Цивільного кодексу України у зв'язку з тим, що він гармонійно вписується у систему правових засобів захисту суб'єктивних цивільних прав та може позитивно вплинути на рівень їх правового забезпечення. Укладення договору на підставі рішення суду передбачає відсутність волевиявлення одного із суб'єктів, що хоча і виглядає як відхід від загальноприйнятої концепції вільного волевиявлення як необхідної умови формування цивільного правовідношення, являє собою ефективний спосіб захисту суб' єктивних цивільних прав і законних інтересів, зокрема учасників переддоговірних відносин. 3 одного боку виникнення суб' єктивних цивільних прав вимоги і кореспондуючих їм суб'єктивних цивільних обов’язків, що входять до змісту договірних правовідносин, має відповідати потребам відповідних суб'єктів цивільного права. Однак, 3 іншого боку, слід зважати і на те, що в конкретних умовах, наприклад, за наявності попереднього договору, хоча укладення відповідного основного цивільно-правового договору може задовольняти потреби лише однієї сторони, друга сторона взяла на себе обов'язок укласти такий договір чим обмежила свою волю. Практика розгляду відповідних категорій справ господарськими судами демонструє ефективність такого правового засобу, як укладення договору за рішенням суду.

Ключові слова: виникнення прав, укладення договору, форма договору, право вимоги, рішення суду

Постановка наукової проблеми та її значення. В сучасних реаліях проблема волевиявлення у ході укладення цивільно-правових договорів, що спричиняють виникнення у їх сторін, зокрема суб' єктивних цивільних прав вимоги, проявляється переважно в двох аспектах. 3 одного боку останні тенденції практики правореалізації свідчать про існування в суспільстві запиту на спрощення форми вчинення правочинів, зокрема укладення цивільно-правових договорів. Цивільний оборот набув

(C) Погребняк В., 2020 
таких обертів, що його учасники намагаються уникати слідування складним і обтяжливим процедурам і надають перевагу спрощеним формам, зокрема вчиненню правочинів конклюдентними діями, за допомогою електронно-цифрових засобів або у спрощеній письмовій формі. Однак, з іншого боку, поглиблення диспозитивного підходу до правового регулювання цивільних відносин пов'язується 3 виникненням ситуацій, коли суб'єкти цивільного права відмовляються укладати договори в правовій обстановці де це явно порушує суб' єктивні цивільні права та/або законні інтереси інших осіб. Йдеться, зокрема, про відмову від укладення основних договорів за наявності попередніх, укладенні публічних договорів тощо. Ці обставини обумовлюють потребу в зверненні відповідних осіб чиї права та/або законні інтереси порушені до альтернативних способів налагодження відносних цивільних правовідносин з відповідними суб’єктами.

Аналіз останніх досліджень і публікацій. Проблеми волевиявлення суб'єктів цивільного права при здійсненні юридично-вагомої поведінки, що пов'язується з виникненням, переходом та/або припиненням суб'єктивних цивільних прав ставали предметом розгляду таких вчених юристів, як М. М. Агарков, С. С. Алексєєв, Б. Віндшейд, Н. Ю. Голубєва, . Дернбург, І. В. Жилінкова, О. С. Іоффе, I. Р. Калаур, А. О. Кодинець, А. В. Коструба, О. О. Кот, О. В. Кохановська, О. О. Красавчиков, Є. О. Крашенінніков, В. М. Крижна, Н. С. Кузнецова, Р. А. Майданик, Є. О. Мічурін, В. В. Надьон, О. О. Отраднова, М. Д. Пленюк, Я. М. Романюк, І. В. Спасибо-Фатєєва, Р. О. Халфіна, С. О. Харитонов, В. В. Цюра, Я. М. Шевченко, С. І. Шимон, Р. Б. Шишка, О. А. Явор, В. Л. Яроцький та ін.

Формулювання мети та завдань статті. Мета статті полягає у визначенні ролі волевиявлення при укладенні договорів за рішенням суду, а також при зверненні учасників процесу укладення договору до спрощених способів оформлення досягнутих домовленостей.

Виклад основного матеріалу й обгрунтування отриманих результатів дослідження. В сучасній юридичній літературі вільне волевиявлення як прояв свободної волі розглядається в якості однієї з визначальних ознак поведінки відповідних осіб при укладенні договору [1, с. 45; 2, с. 53]. Це загальне правило, що детермінує сутність цивільно-правового договору як інструмента правового саморегулювання суспільних відносин. Відповідна юридична схематизація передбачає формування у потенційних учасників договірних правовідносин волі на налагодження відповідних юридичних зв'язків. Цей процес пов'язаний з формуванням мотиву як наміру набути відповідні суб'єктивні цивільні права та/або взяти на себе суб'єктивні цивільні обов'язки задля задоволення певних потреб, що втілюється в законному інтересі як намаганні отримати відповідні правові можливості. Таким чином свобода волі є одним з визначальних факторів набуття договірних суб'єктивних цивільних прав вимоги, адже, за загальним правилом, особа вступає у договірне правовідношення добровільно.

Поряд із цим в контексті зазначеного необхідно зважати на те, що в окремих випадках факту укладення договору може передувати певний договірний процес учасники якого беруть на себе, зокрема суб'єктивні цивільні обов'язки, пов'язані з укладенням договору. Крім того, правове становище одного із суб'єктів цивільного права може обумовлювати необхідність укладення ним відповідного цивільного договору. При цьому така необхідність може бути пов'язана як 3 необхідністю набуття ним певних суб'єктивних цивільних прав, так і обов'язків. І в такому разі сама обстановка обумовлює потребу в укладенні договору незалежно від того, що лише один 3 потенційних учасників правовідношення має мотив вступити в них.

В цьому сенсі слід визнати, що в положеннях чинного цивільного законодавства України проблемі переддоговірних цивільних відносин не присвячено належної уваги, що негативно відображається на рівні юридичної забезпеченості суб'єктивних цивільних права учасників процесу укладення цивільно-правового договору. І в цьому сенсі ми можемо спостерігати різницю в підходах до вирішення проблем відповідної сфери, що знайшли втілення, зокрема в положеннях Цивільного кодексу України (далі - ЦК України) та Господарського кодексу України (далі - ГК України).

В цьому сенсі ст. 187 ГК України фактично запроваджує виключення із загального правила, яке вимагає наявність свободної волі і вільного волевиявлення як необхідних елементів процесу формування договірного цивільного правовідношення. Цим нормативним положенням встановлюється, що судом розглядаються спори, що виникають при укладенні господарських договорів за державним замовленням або договорів, укладення яких є обов'язковим на підставі закону та в інших випадках. При цьому цим нормативним положенням також встановлюється, що предметом розгляду суду можуть бути інші переддоговірні спори у разі, якщо це передбачено угодою сторін або якщо сторони зобов' язані укласти певний господарський договір на підставі укладеного між ними попереднього договору [3, ст. 187]. Однак, важливе значення має те, що ч. 2 аналізованого нормативного положення встановлюється, що день набрання чинності рішенням суду, яким вирішено 
питання щодо переддоговірного спору, вважається днем укладення відповідного господарського договору, якщо рішенням суду не визначено інше [3, ст. 187]. Це нормативне положення є унікальним за змістом, оскільки слугує ефективним нормативним інструментом вирішення переддоговірних спорів.

Ця проблема має найбільшу актуальність при вирішенні цивільних спорів в рамках цивільного судочинства, оскільки, незважаючи на те, що ЦК України визначає в якості одного зі способів захисту суб'єктивних цивільних прав і законних інтересів учасників правовідносин виконання обов'язку в натурі (п.5 ч. 2 ст. 16 ЦК України) [4, ст. 16], тим не менше, наразі положення основного акту цивільного законодавства України не наділяють суб'єктів правозастосування ефективним інструментарієм для вирішення відповідних юридичних конфліктів. Крім того, в контексті доктрини вільного волевиявлення 3 цим пов'язується одночасно декілька проблем, зокрема, чи може суд зобов'язати суб' єкта цивільного права вступити в договірні правовідносини? Як забезпечити виконання такого рішення суду? При цьому необхідно враховувати і те, що ймовірність притягнення особи, яка не виконує рішення суду, до кримінальної відповідальності не вирішує проблему виникнення правовідношення, а тому і суб' єктивного цивільного права вимоги, що входить до його змісті і у виникненні якого зацікавлений потенційний кредитор у відповідному зобов'язанні.

В ЦК України проблемі вирішення переддоговірних спорів присвячена ст. 649, яка, однак, не наділяє суд безпосередньо правом налагоджувати договірні відносини між суб'єктами цивільного права при розгляді переддоговірних спорів в рамках цивільного судочинства. Суд наділений правом змінювати та/або розривати договори (ст. 651 ЦК України [4, ст. 651]), однак не наділений можливістю налагоджувати договірні цивільні правовідносини між відповідними особами. Як наслідок, при розгляді відповідних категорій справ в рамках цивільного судочинства, як правило, на рівні суду апеляційної інстанції скасовуються рішення місцевих судів якими задоволено позови щодо зобов'язання певних осіб укласти визначені договори (одним з прикладів цьому виступає, зокрема ухвала Вищого спеціалізованого суду України з розгляду цивільних і кримінальних справ від 23 вересня 2013 року у справі № 6-31564ск13 [5]). Тим не менше, якщо неукладення договору пов'язується із завданням збитків, суди вирішують відповідні спори поза проблемою зобов'язання до укладення договору. Наприклад, у справі № 6-225св09 Верховним Судом України залишено в силі рішення Краснолиманського міського суду Донецької області від 10 вересня 2008 року та ухвалу апеляційного суду Донецької області від 11 листопада 2008 року, яким задоволено позов в частині стягнення на користь позивача (Комунальне підприємство «Краснолиманська житловоексплуатаційна контора») заборгованості за утримання будинку і прибудинкової території, однак відмовлено в частині зобов'язання відповідача укласти договір про надання послуг з утримання будинку i споруд, прибудинкової території, опалення, постачання холодної та гарячої води, водовідведення [6]. Таким чином, судом вирішено питання про відшкодування збитків, однак не покладено на споживача відповідних послуг обов'язку укласти договір.

В цьому сенсі ст. 187 ГК України демонструє свою ефективність в практиці вирішення відповідних категорій справ. Зокрема, в ході проведення ПАТ «Українська залізниця» процедури закупівлі - відкритих торгів визначеного майна протягом 2016 року згідно протоколу оцінки пропозицій конкурсних торгів від 13 червня 2016 року № 5/6 пропозиція ТОВ «Науково-виробничий комплекс «Дніпроспецмаш» визнана найбільш економічно вигідною. При цьому повідомленням від 13 червня 2016 року № 18-23/1-53 про акцепт пропозиції конкурсних торгів установлено строк укладення договору про закупівлю (рамкова угода) - не пізніше 13 липня 2016 року. Інші учасники конкурсних торгів подали скарги до Антимонопольного комітету України про порушення замовником порядку проведення процедури закупівлі за результатами розгляду яких отримали відмову в їх задоволенні (рішення Комітету від 26 липня 2016 року). Однак, рішенням комітету конкурсних торгів ПАТ «Українська залізниця», оформлених протоколом від 19 серпня 2016 року № 33/16 відмінено конкурсні торги на закупівлю.

Позивач вважав, що з моменту визначення переможця торгів та акцептування його пропозиції відповідач не мав права відміняти процедуру закупівлі, що й спричинило спір.

Вищий господарський суд визнав обгрунтованим висновок судів першої і апеляційної інстанцій про задоволення позовних вимог у частині визнання спірного договору про закупівлю укладеним з дня набрання рішенням суду законної сили [7].

При цьому, при вирішенні відповідних справ, пов'язаних зі сферою житлово-комунальних послуг господарські суди, за наявності необхідних правових вимог задовольняють позови в частині визнання укладеними відповідні договори 3 дня набрання рішенням суду законної сили. В якості прикладу можна навести рішення господарського суду міста Києва від 19 лютого 2007 року у справі 
№ 7/47 за позовом ВАТ «Акціонерна компанія «Київводоканал» до ТОВ «Житловик-Плюс», яким вирішено вважати укладеним 3 дня набрання даним рішенням законної сили, договір на поставку питної води та приймання стічних вод через приєднані мережі № 06963/2-01 від 06 жовтня 2006 року на умовах, запропонованих ВАТ «Акціонерна компанія «Київводоканал». На це рішення як підставу виникнення договірного правовідношення між зазначеними суб'єктами посилається Вищий господарський суд України від 03 квітня 2013 року у справі № 5011-16/11467-2012 [8].

3 наведеного слідує, що рішення суду, будучи актом правозастосування, може виступати в механізмах виникнення, переходу та припинення суб' єктивних цивільних прав засобом встановлення юридично важливих обставин правої реальності та/або юридичним фактом як самостійною правовстановлюючою підставою, так і елементом юридичного складу.

В той же час активний розвиток комунікаційних технологій сприяє розвитку форм договорів $\mathrm{i}$ забезпечуючи оперативність в налагодженні майнових відносин між учасниками майнового обороту прискорює останній. У зв' язку з цим актуальною проблемою сучасних договірних відносин виступає симпліфікації форм фіксації домовленостей між суб'єктами цивільного права. В сучасних умовах простежується послаблення законодавчих вимог, що висуваються до форми договорів, надання переваги сутності договору як домовленості порівняно з його формою, відкривається можливість використання альтернативних способів фіксації досягнутої згоди. Безумовно, це робить переддоговірний процес більш доступним i, крім того, прискорює майновий оборот. Зокрема, вже у 2015 році до ч. 2 ст. 639 ЦК України було внесено зміни, якими чітко запроваджено можливість укладення договору за допомогою інформаційно-телекомунікаційних систем [4, ст. 639]. При цьому ст. 181 ГК України прямо допускає укладення договорів у спрощений спосіб, зокрема шляхом обміну листами, факсограмами, телеграмами, телефонограмами тощо [3, ст. 181].

У зв'язку з цим в практиці правореалізації і правозастосування вагоме значення починає відігравати не стільки форма домовленості, скільки ії сутність. Це витікає і з абз. 2 ч. 1 ст. 218 ЦК України [4, ст. 218]. В рамках окресленого підходу форма договору не вводиться в абсолют і виконує, можна сказати, технічну функцію фіксації основного змісту досягнутої домовленості. У зв'язку з цим, визначальним в сутності договору є саме наявність домовленості як взаємного узгодження волі осіб, в той час як визначальним у формі фіксації такої домовленості, є відображення їі змісту. В контексті феномену наявності у договору правовстановлюючої властивості за відсутності узгодженнях всіх істотних умов, вбачається, що мінімально необхідним для наявності такої властивості є узгодження об'єкта договору. В такому разі за наявності суб'єктів як визначальної умови виникнення правовідношення, зміст останнього формується, якщо інше не встановлено самим договором або законом, звичайним для таких правовідносин змістом.

Висновки. Підводячи підсумок під викладеним вище необхідно відзначити, що сучасні тенденції розвитку майнового обороту дозволяють стверджувати, що, по суті, ми $є$ свідками того, як зміщуються акценти стосовно однієї 3 найфундаментальніших проблем цивільного права. Якщо раніше іiі сутність полягала в узгодженні волі і волевиявлення, то в сучасних умовах більшого значення набуває саме зовнішня форма прояву волі, тобто волевиявлення. Учасники майнового обороту бажають вчиняти двосторонні правочини ефективно і оперативно без зайвих формальностей. За такого підходу наявність волі презюмується.

В цьому сенсі укладення договору на підставі рішення суду, що передбачає, зокрема відсутність волевиявлення одного із суб'єктів, хоча і виглядає як відхід від загальноприйнятої концепції вільного волевиявлення як необхідної умови формування цивільного правовідношення, або як в певній мірі радикальний крок, однак, все ж таки, являє собою ефективний спосіб захисту суб'єктивних цивільних прав і законних інтересів, зокрема учасників переддоговірних відносин. Дійсно, 3 одного боку виникнення суб'єктивних цивільних прав вимоги і кореспондуючих їм суб' єктивних цивільних обов'язків, що входять до змісту договірних правовідносин, має відповідати потребам відповідних суб'єктів цивільного права. Однак, з іншого боку, слід зважати і на те, що в конкретних умовах, наприклад, за наявності попереднього договору, хоча укладення відповідного основного цивільно-правового договору може задовольняти потреби лише однієї сторони, друга сторона взяла на себе обов' язок укласти такий договір чим обмежила свою волю.

В контексті зазначеного, вважаємо, практика розгляду відповідних категорій справ господарськими судами демонструє ефективність такого правового засобу як укладення договору за рішенням суду. Адже, незважаючи на те, що в такому разі договірні суб'єктивні цивільні права, по суті, виникають за волевиявленням лише одного з учасників правовідношення, сутність такого правовідношення не змінюється. Воно залишається договірним за своєю природою. Його виникнення $€$ закономірним наслідком, який повинен враховуватись особою, яка ухиляється від укладення 
договору, зокрема внаслідок укладення попереднього договору або із початком зайняття діяльністю, яка передбачає укладення публічних договорів. Відповідний механізм, що знайшов відображення, зокрема в ст. 187 ГК України, вважаємо, повинен бути запроваджений і на рівні відповідних положень ЦК України, щонайменше у зв'язку з тим, що він гармонійно вписується в систему цивільно-правових засобів захисту суб'єктивних прав і може позитивно вплинути на рівень їх правового забезпечення.

\section{Джерела та література}

1. Беляневич О. А. Договір як засіб саморегуляції господарських відносин: загальна характеристика / О. А. Беляневич // Бюл. М-ва юстиції України. - 2005. - № 8 (46). - С. 40-48.

2. Гольцов В. Б. О понятии договора в гражданском праве / В. Б. Гольцов // Известия высш. учеб. заведений. - Правоведение. - 2005. - № 4. - С. 46-55.

3. Господарський кодекс України: Закон України від 16.01.2003 p. № 436-IV // Відом. Верхов. Ради України. - 2003. - № 18, № 19-20, № 21-22. - Ст. 144 (із змінами).

4. Цивільний кодекс України: Закон України від 16.01.2003 p. № 435-IV // Відом. Верхов. Ради України. - 2003. - №№ 40-44. - Ст. 356 (із змінами).

5. Ухвала Вищого спеціалізованого суду України з розгляду цивільних і кримінальних справ від 23.09.2013 р., судова справа № 6-31564ск13. - Режим доступу: http://reyestr.court.gov.ua/Review/ 33735944.

6. Ухвала Верховного Суду України від 06.03.2009 р., судова справа № 6-225св09. - Режим доступу: http://reyestr.court.gov.ua/Review/3285338.

7. Постанова Вищого господарського суду України від 01.03.2017 р., судова справа № 910/16460/16. Режим доступу: http://reyestr.court.gov.ua/Review/65081235.

8. Постанова Вищого господарського суду України від 03.04.2013 р., судова справа № 5011-16/114672012. - Режим доступу: http://reyestr.court.gov.ua/Review/30436546.

Погребняк В. Отдельные проблемы волеизъявления в ходе возникновения договорных субъективных гражданских прав. Статья посвящена рассмотрению роли волеизъявления в ходе возникновения субъективных гражданских прав при формировании договорного гражданского правоотношения. Соответствующая юридическая схематизация рассматривается, в частности, с позиций принципа свободы воли и свободного волеизъявления, а также в контексте правоприменительной практики высших судебных инстанций Украины. Автор рассматривает проблему заключения договора по решению суда, а также анализирует современные тенденции практики правореализации в части оформления договоров. Формируется вывод о том, что механизм заключения договоров по решению суда, который нашел отображение на уровне положений Хозяйственного кодекса Украины, может быть внедрен и на уровне Гражданского кодекса Украины в связи с тем, что он гармонично вписывается в систему правовых средств защиты субъективных гражданских прав и может позитивно повлиять на уровень их правового обеспечения. Заключение договора на основании решения суда предполагает отсутствие волеизъявления одного из субъектов, хотя и выглядит как отход от общепринятой концепции свободного волеизъявления как необходимого условия формирования гражданского правоотношения, представляет собой эффективный способ защиты субъективных гражданских прав и законных интересов, в том числе участников преддоговорных отношений. С одной стороны, возникновение субъективного гражданского права требования и корреспондирующих им субъективных гражданских обязанностей, которые входят в содержание договорных правоотношений, должны соответствовать потребностям соответствующих субъектов гражданского права. С другой стороны, следует учитывать и то, что в конкретных условиях, например, при наличии предварительного договора, хотя заключение соответствующего основного гражданско-правового договора может удовлетворять потребности только одной стороны, другая сторона взяла на себя обязанность заключить такой договор, чем ограничила свою волю. В контексте указанного, считаем, практика рассмотрения соответствующих категорий дел хозяйственными судами демонстрирует эффективность такого правового средства, как заключение договора по решению суда.

Ключевые слова: возникновение прав, заключение договора, форма договора, право требования, решение суда 
Pohrebniak V. Some Issues of the Expression of Will in the Contractual Subjective Civil Rights. The article highlights the role of the expression of will concerning the subjective civil rights emergence in the course of the contract civil legal relations formation. The author focuses on the issue of concluding a contract by a court decision and analyzes the current trends in the practice of law enforcement in terms of contract engrossment. The article considers the appropriate legal scheming of contract from the standpoint of the principle of freedom of will and the free expression of will, including the law enforcement practice context of the highest courts in Ukraine. The author concludes that the mechanism of concluding agreements/contracts by a court decision, which reflects mainly the provisions of Commercial Code of Ukraine, can be applied at the level of Civil Code of Ukraine since it harmoniously fits into the legal protection system concerning the subjective civil rights and may positively influence their legal support level. The making a contract based on a court decision provides for the absence of will of one of the parties, which although looks like a departure from the generally accepted concept of free will as a necessary condition for the formation of civil law. But it is an effective way to protect subjective civil rights and legitimate interests of participants in pre-contractual relations. On the one side, the emergence of subjective civil rights of claim and their corresponding subjective civil obligations, which are part of the content of the contractual relationship, must meet the needs of the relevant subjects of civil law. On the other side, it should be taken into account that in specific circumstances, for example, in the presence of a preliminary agreement, if even the conclusion of the relevant basic civil contract may meet the needs of only one party, another party undertook to enter into such an agreement and it leaded to limiting her will. In the context of the above, we consider that the practice of consideration of the relevant categories of cases by commercial courts demonstrates the effectiveness of such a remedy as the making a contract based on a court decision.

Key words: origin of rights, concluding a contract, form of contract, right of claim, court decision

УДК 347.1

DOI https://doi.org/10.32782/2409-4544/2020-1/12

Н.Чубоха

\section{До питання інтересів у цивільному праві}

У статті досліджується поняття інтересу як цивільно-правової категорії та його співвідношення з об'єктивним правом. Обгрунтовується дефініція інтересів як усвідомлених прагнень і потреб особистості, її вольових дій, спрямованих на досягнення певного правомірного результату, набуття і здійснення суб'єктивних цивільних прав. Обгрунтовано необхідність розмежування інтересу і об'єктивного цивільного права, визначаються механізми їх здійснення в цивільному праві. Спростовується необхідність застосування категорії законного інтересу, який слід вважати природним інтересом людини, оскільки це позаправова категорія, яка грунтується на соціальних і морально-етичних нормах. Автор дійшов висновку, що природний інтерес - це різновид інтересу, який не визначений об'єктивним правом і $є$ відповідним простим фактичним рішенням особи діяти на власний розсуд для досягнення конкретних соціальних благ. Як позаправова категорія, він $\epsilon$ передумовою суб'єктивного права особи і визначається як допустима в майбутньому соціальна поведінка особи, яка відповідає духу, сутності права або не суперечить їм, і здійснюється за принципом «дозволено те, що не заборонено законом». Зміст такого інтересу складається 3 двох прагнень людини: по-перше, фактичного - користуватися певним соціальним благом в рамках загальних дозволів і, по-друге, морально-етичного - звертатися в необхідних випадках за захистом від порушення (неможливості) реалізації прагнень людини.

Ключові слова: приватний інтерес, публічний інтерес, об’єктивне право, суб'єктивне право.

Постановка наукової проблеми та її значення. Відсутність в науковій доктрині єдності у розумінні категорії «інтерес», його ролі та місця серед інших категорій цивільного права. У сфері цивільно-правового регулювання інтерес є метою, певною рушійною силою поведінки суб' єктів, спонуканням особи до дій для досягнення результату у цивільних правовідносинах. Саме формування

() Чубоха Н., 2020 